\title{
„MINIMALNE” MANIPULACJE, CZYLI KONSEKWENCJE POLITYCZNE ZMIANY STRUKTURY OKRĘGÓW WYBORCZYCH W WYBORACH DO SEJMU RP
}

\author{
Jarosław Flis* \\ Uniwersytet Jagielloński
}

\section{Bartłomiej Michalak** Uniwersytet Mikołaja Kopernika w Toruniu}

Streszczenie: W debacie publicznej co jakiś czas pojawiaja się gtosy o potrzebie istotnej zmiany systemu wyborczego w wyborach do Sejmu RP, której celem miatoby być wzmocnienie silniejszych ugrupowań. Jako przyktad podaje się Węgry, gdzie zmiana regut wyborczych pozwolita partii rzadzacej zachować większość mimo zmniejszenia poparcia wyborczego. Przeciwnicy takiego rozwiazania traktuja to jako przejaw oczywistej manipulacji wyborczej. Celem tego artykutu jest analiza, na ile pojawiajace się $w$ debacie publicznej propozycje "minimalnych” zmian w strukturze sejmowych okręgów wyborczych wptynętyby na wyniki wyborcze poszczególnych ugrupowań politycznych i jakie wywołałoby to konsekwencje polityczne, w szczególności w kwestii premii dla ugrupowania zwycięskiego, możliwych wariantów koalicji rzadowych, koncentracji systemu partyjnego na poziomie parlamentarnym i poziomu proporcjonalności wyborów. Przeprowadzona symulacja podziału głosów na mandaty - na podstawie danych historycznych (wybory z lat 2011 i 2015) oraz europejskich z 2019 roku - dla trzech możliwych do zastosowania wariantów struktury sejmowych okręgów wyborczych oraz ich porównanie z wynikami obecnego systemu pozwoli udzielić odpowiedzi na te pytania.

Stowa kluczowe: okręgi wyborcze, manipulacje wyborcze, odchylenia od proporcjonalności, wybory parlamentarne w Polsce.

\footnotetext{
* Jarosław Flis, Instytut Dziennikarstwa, Mediów i Komunikacji Społecznej Uniwersytetu Jagiellońskiego, ul. prof. Stanisława Łojasiewicza 4, 30-348 Kraków, e-mail: jaroslaw.flis@uj.edu.pl

** Bartłomiej Michalak, Wydział Politologii i Studiów Międzynarodowych UMK, ul. Stefana Batorego 39L, 87-100 Toruń, e-mail: bartlomiej.michalak@umk.pl
} 


\section{"MARGINAL" MANIPULATIONS, OR POLITICAL CONSEQUENCES OF CHANGES TO THE STRUCTURE OF CONSTITUENCIES IN ELECTIONS TO THE POLISH LOWER PARLIAMENTARY CHAMBER}

Abstract: In the Polish public debate, one occasionally hears voices advocating the need for a significant change in the system of elections to Sejm, the Lower Chamber of Parliament - the objective of such changes would be to strengthen larger parties. As an example to follow, proponents of these changes cite Hungary, where the changes in electoral rules allowed the party in power to retain majority in the legislative despite reduction in popular support. Opponents of this solution see it as a manifest electoral manipulation. The aim of the present paper is to analyze how the "marginal only" changes to the structure of constituencies electing members of Sejm postulated in the political arena would affect electoral results of individual political groups and what would be the broader political consequences. The author pays particular attention to expected impact of such changes on the majority bonus for the winning party, possible government coalition variants, concentration of party system at parliamentary level and proportionality of elections. Simulation of allocation of seats in Sejm based on votes cast was prepared for three possible variants of the structure of Sejm constituencies, on the basis of historical data (for the 2011 and 2015 elections) and the predicted results of 2019 elections. Comparison of the simulated outcomes with the results obtained in the system currently in place allows to answer the main question posed.

Key words: electoral districts, electoral manipulations, deviations from proportionality, parliamentary elections in Poland.

Prawo i Sprawiedliwość (PiS) po zwycięstwie w 2015 roku podjęło szereg zdecydowanych działań, istotnie zmieniających dotychczasowe reguły działania polskiego państwa. Stąd w debacie publicznej pojawiły się spekulacje dotyczące możliwości objęcia zmianami także systemu wyborczego (Grochal, 2016; Noch, 2016). W szczególności, przywoływane były tu doświadczenia Węgier, gdzie zmiana systemu wyborczego pozwoliła rządzącej partii Fidesz na zachowanie swego stanu posiadania w parlamencie pomimo istotnego spadku poparcia (Drinóczi, 2014; Toka, 2014). Potencjał tego kierunku zmian - wprowadzenia ordynacji mieszanej - został już omówiony w literaturze przedmiotu (Flis i Michalak, 2017). Drugą publicznie rozważaną opcją była modyfikacja obecnego systemu wyborczego - w szczególności zwiększenie liczby 
okręgów. Jeden z liderów obozu rządzącego - marszałek Senatu Stanisław Karczewski - publicznie popierał taką ewentualną zmianę (PAP 2017). W debacie pojawiły się także ostrzeżenia przed możliwością manipulacji wielkością okręgów w zależności od skali poparcia dla rządzącej partii (Kublik i Markowski, 2016). Przedstawiany artykuł eksploruje dwa ostatnie wątki. W analizie wzięto pod uwagę takie zmiany systemu wyborczego, które zachowują rdzeń obecnego systemu wyborczego, czyli wielomandatowe okręgi wyborcze i podział mandatów przy wykorzystaniu metody d'Hondta, zmieniając jednak liczbę i kształt okręgów. Celem tego artykułu jest przetestowanie, jakie konsekwencje polityczne przyniosłoby przeprowadzenie takiej ewentualnej zmiany w wyborach do Sejmu RP. Test ten składać się będzie z dwóch operacji. Pierwsza pokazuje możliwe mechaniczne efekty różnych wariantów systemu wyborczego - czyli rezultaty przeliczenia w ramach takiego systemu wyników wcześniejszych wyborów. Druga to pokazanie możliwych efektów strategicznych, czyli wpływ ordynacji na korzyści i straty wynikające z ewentualnego skłonienia partii opozycyjnych do współpracy w obliczu takiej zmiany. Całość uzupełniają rozważania na temat możliwych zmian zachowań wyborców oraz kandydatów. Dzięki zastosowaniu symulacji możliwe będzie zidentyfikowanie konsekwencji politycznych w najważniejszych obszarach oddziaływania systemu wyborczego na system partyjny - są to: potencjalni beneficjenci nowych rozwiązań, stopień koncentracji systemu partyjnego na arenie parlamentarnej oraz odchylenie tych systemów od proporcjonalności podziału.

\section{WIELKOŚĆ OKRĘGU JAKO CECHA SYSTEMOWA}

Okręg wyborczy to jednostka administracji wyborczej obejmująca swym zasięgiem pewną liczbę obywateli, gdzie w drodze głosowania dokonuje się wyboru spośród zgłoszonych oficjalnie kandydatów, osoby czy osób do pełnienia pewnej funkcji (np. reprezentowania danej grupy). W wyborach do organów kolegialnych, takich jak parlamenty, dla których podstawową funkcją jest odzwierciedlanie i reprezentowanie interesów i potrzeb społecznych, istotą okręgów wyborczych jest w pierwszej kolejności zapewnienie reprezentacji geograficznej (Reynolds i in., 2008, s. 9). Jednocześnie to w ich obrębie dokonuje się transformacja głosów wyborczych w określony układ polityczny. Wielkość okręgu, który jest kluczowym czynnikiem przy zapewnieniu reprezentacji terytorialnej, ma dokładnie przeciwstawne oddziaływanie w przypadku odzwierciedlania subtelności podziałów ideowych. Oczywistością dla badaczy systemów politycznych jest reguła micro-mega - „mali lubią duże, duzi lubią małe” (Colomer, 2004)1. Reguła ta ma jednak mniej oczywiste konsekwencje dla ogólnej oceny systemów politycznych.

1 Na fakt ten wskazywali między innymi: Rae (1967), Taagepera i Laakso (1980), Taagepera (1986) oraz Taagepera i Shugart (1989). 
Fakt, że proporcje w podziale mandatów mogą odbiegać od proporcji głosów, bywa różnie interpretowany. Odchylenie od proporcjonalności jest oczywistą cechą każdego systemu wyborczego, który ze swojej natury jest mechanizmem redukującym liczbę partii politycznych. Zdaniem niektórych badaczy nie jest to nawet wada, gdyż proporcjonalność podziału wcale nie musi być najważniejszym celem wyborów. Może nim być natomiast końcowa polityka rządu uwzględniająca preferencje różnych grup społecznych. Problem ten dobrze wyłożył Dieter Nohlen (2004, s. 129 i n.) klasyfikując systemy wyborcze w zależności od tego, jaki cel reprezentacji optymalizują: większościowy (utworzenie stabilnego rządu i czytelnego układu polityczne) czy proporcjonalny (możliwie najpełniejsze odzwierciedlenia preferencji politycznych wyborców).

Jednak bez względu na to, który cel reprezentacji uznajemy za ważniejszy w danych warunkach społeczno-politycznych, proporcjonalność w relacji głosy-mandaty jest jedną z głównych funkcji, których wypełnienia oczekuje się od systemu wyborczego (Nohlen, 2004, s. 402). Nadmierne odchylenie od proporcjonalności może bowiem godzić w legitymację całego systemu politycznego (Taagepera, 2007, s. 65). Wśród badaczy systemów politycznych istnieje niemal powszechna zgoda co do tego, że proporcjonalność wyborów jest jednym z głównych kryteriów oceny systemu wyborczego (Gallagher, 2005, s. 570-572).

Tu pojawia się napięcie pomiędzy samym mechanizmem systemu wyborczego a jego efektem na wyjściu. Proporcjonalność „na wyjściu” - rozumiana jako możliwie pełna zgodność udziału w otrzymanym poparciu i udziału w zdobytych głosach - wcale nie musi być oczywistym rezultatem oparcia systemu wyborczego na proporcjonalności „na wejściu”, czyli na wielkości udziału (Raciborski, 2006; Flis, 2014, s. 30-31). Nie brakuje jednak głosów, że efekt dysproporcjonalności jest nie tylko naturalny, ale może być wręcz pożądany. Cechą systemu może być superaddytywność, czyli zjawisko polegające na tym, że koalicja dwóch partii otrzymuje nie mniej mandatów, niż otrzymałyby jej składowe, startując osobno (Haman, 2003, s. 145-146). Zachęca to do przedwyborczych porozumień partie, co wcale nie jest oczywiste, zważywszy na możliwe odpływy części wyborców w przypadku tworzenia szerszych ugrupowań (Kamiński, 2001). Cecha taka może być założona a priori, prowadząc do stworzenia rozwiązania nazwanego przez Jacka Hamana (2017) „progresywną proporcjonalnością", w którym związek pomiędzy udziałem w oddanych głosach a udziałem w zdobytych mandatach jest nieliniowy - przyrost liczby mandatów jest szybszy od wzrostu udziałów w poparciu. Takie rozwiązanie może z kolei mieć wpływ na stabilność rządów (Taagepera i Sikk, 2010). Analizy danych empirycznych dowodzą, że dysproporcjonalny system wyborczy sprzyja trwałości rządu. Natomiast stabilność rządów jest już bez wątpienia cechą ocenianą pozytywnie. Nie jest jednak oczywiste, jaką cenę można zapłacić za taką cechę systemu politycznego - w szczególności czy tworzenie sztucznych większości parlamentarnych, które nie mają poparcia więk- 
szości obywateli, nie podważa wiarygodności systemu demokratycznego. Jedno jest natomiast pewne - efekty zmiany liczby okręgów wyborczych można szacować na podstawie matematycznego modelu (Flis, Słomczyński i Stolicki, 2019) lub też poddać je testowi w oparciu o historyczne wyniki i konkretny podział na okręgi. Artykuł ten podąża drugą z tych ścieżek.

\section{PoDZIAEY CELOWE SKRZYWIONE}

Przyjmuje się, że stosowany w USA system większości względnej oparty na jednomandatowych okręgach wyborczych jest podatny na manipulacje (Markowski, 2010). Potencjalne manipulacje mogą opierać się na różnych odmiennych sposobach (Grofman, Koetzle i Brunell, 1997). Przede wszystkim będzie to klasyczny gerrymandering polegający na politycznie motywowanym wytyczaniu granic okręgów wyborczych. Można to robić z uwzględnieniem frekwencji wyborczej, co przesądzić może o sile indywidualnego głosu w poszczególnych okręgach. Można też maksymalizować liczbę głosów zmarnowanych w przypadku jednych partii, zaś minimalizować ją w przypadku innych. Do manipulacji można też wykorzystać efekty zjawiska znanego w literaturze przedmiotu jako malapportionment, a polegającego na nierównej (nieproporcjonalnej) wielkości reprezentacji w poszczególnych okręgach wyborczych. Należy podkreślić, że z empirycznego punktu widzenia jest to zjawisko naturalne. Kluczowa jest jednak jego skala. Granice tolerancji decydentów dla odstępstw od wymogu równości materialnej głosu (równej siły głosu) są przekraczane czasami tak dalece, że można je uznać za przejaw manipulacji (Nohlen, 2004, s. 76). Jest to jednak manipulacja wyrażająca się $\mathrm{w}$ wieloletnim utrzymywaniu niezmienionych granic okręgów wyborczych (z reguły jednomandatowych), mimo zaistniałych znaczących zmian demograficznych, w przeszłości polegających głównie na migracji ludności ze wsi do miast, co w konsekwencji prowadziło do uprzywilejowania wyborców zamieszkujących obszary wiejskie, a więc z reguły bardziej prawicowo zorientowanych. Malapportionment wystąpił w USA, Wielkiej Brytanii czy we Francji (Haman, 2003, s. 180, 183-184). W Japonii ułatwił Partii Liberalno-Demokratycznej - w połączeniu z dysproporcjonalnymi właściwościami stosowanego w tamtym czasie systemu pojedynczego głosu nieprzenoszonego (SNTV) - utrzymanie pozycji hegemonicznej w systemie partyjnym przez ponad cztery dekady (Koellner, 2005, s. 12).

W przypadku wielomandatowych okręgów wyborczych wszystkie te metody świadomej manipulacji niosą znacznie mniej zagrożeń. Przede wszystkim, mniej jest samych okręgów, stąd nawet jeśli w każdym z nich można byłoby uzyskać podobnej wielkości "nagrodę” na skutek manipulacji, to suma takich nagród będzie jakościowo mniejsza. Jednocześnie okręgi wielomandatowe stanowią znacznie większe „ziarno”, 
stąd te same odchylenia od np. normy reprezentacji niosą w ich przypadku znacznie mniejsze zagrożenia dla ostatecznego wyniku (Flis i Stolicki, 2015). Niemniej jednak i tutaj odnaleźć można przypadki, gdy konkretny podział na okręgi prowadzi do skrzywienia wyniku. Zróżnicowanie frekwencji w poszczególnych okręgach ma także w przypadku Polski zauważalny wpływ na wynik (Flis, 2014, s. 149-154). Jednak ich geograficzna rozległość w połączeniu z administracyjnymi ograniczeniami przy ich wyznaczaniu stawia granice potencjałowi manipulacyjnemu.

Należy jednak pamiętać, że metoda podziału głosów na mandaty zaproponowana przez Victora d'Hondta, poprzez wspomnianą wyżej regułę micro-mega, otwiera jeszcze jedną potencjalną metodę manipulacji. Polega ona na minimalizowaniu wielkości okręgów na obszarach, gdzie dana partia wygrywa, natomiast maksymalizowaniu jej tam, gdzie wygrywają inne partie, a dana partia jest na dalszej pozycji, jeśli chodzi o kolejność. Zgodnie z modelem Schustera (2003), takie skrzywione podziały mogą oznaczać zauważalne zyski dla jednych partii, straty zaś dla innych. Możliwość taką potwierdziły badania zespołu Otrida Kedara (2015). W państwach, których proporcjonalny system wyborczy opiera się na okręgach różnej wielkości, występują większe odchylenia od proporcjonalności niż w tych, w których okręgi są względnie równe. Wynikać to może z takich zjawisk jak to zaobserwowane w Portugalii: występowanie mniejszych okręgów obok okręgów dużych nie ma tu integrującego wpływu na partie i wyborców, lecz okręgi takie mają istotny wpływ na mechaniczne efekty systemu (Lachat, Blais i Lago, 2015).

\section{ZAŁOŻENIA TESTOWANYCH MODELI ZMIANY}

Z całego spektrum ewentualnych rozwiązań do testu wybrano trzy. Pierwsza opcja polega na zwiększeniu liczby okręgów przy zachowaniu dotychczasowych limitów zapisanych w Kodeksie wyborczym: minimalnego okręgu wyborczego liczącego siedem mandatów oraz zgodności granic okręgów sejmowych z granicami okręgów senackich. Jest to rozwiązanie wymagające możliwie najmniejszych zmian legislacyjnych. Zasadniczy tekst Kodeksu wyborczego pozostaje ten sam, zmienia się tylko treść załącznika (art. 202 § 2) - który i tak musi być stale korygowany ze względu na zmiany demograficzne, co jest wymogiem stawianym przez sam Kodeks wyborczy (art. 203). W ewentualnej debacie dotyczącej takiej zmiany inicjatorzy mogliby się odwołać do argumentu, że sam system pozostaje w takiej sytuacji niezmieniony.

Na przeciwległym biegunie sytuuje się rozwiązanie, w którym jako podstawę podziału w wyborach sejmowych przyjmuje się okręgi senackie w liczbie 100. To oczywiście wymaga stosownej zmiany kodeksowej w zakresie większym niż sam jego za- 
łącznik, konkretnie zaś zmniejszenia minimalnej liczby mandatów w okręgu do trzech. Okręgi tej wielkości były wykorzystywane już w przeszłości podczas wyborów sejmowych w latach 1993 i 1997. Taka wielkość była też przewidziana w zmianach proponowanych przez PiS w przypadku wyborów sejmikowych oraz europejskich. W obu przypadkach nie doszło jednak do wcielenia tych zmian w życie - z pierwszej zmiany obóz rządzący wycofał się na etapie prac parlamentarnych, druga zaś została zawetowana przez prezydenta. Niemniej można przypuszczać, że w przypadku wyborów większej wagi, jakimi są wybory sejmowe, takie rozwiązanie mogłoby zostać przeforsowane.

Obydwa te rozwiązania - przewidujące zachowanie okręgów wyborczych mniejszych niż województwo i wpisujących się w granice okręgów senackich - muszą uwzględniać fakt, że obecny podział na okręgi senackie jest, z uwagi na zmiany demograficzne, de facto niezgodny z normami podziału zapisanymi w Kodeksie wyborczym. Kodeks wyborczy w bardzo nieprecyzyjny sposób reguluje sprawę podziału na okręgi senackie. Jedynym wprowadzonym ograniczeniem jest margines liczby okręgów przypadających na województwo (art. $261 \S 2$ ). Niemniej nawet to słabe ograniczenie zostało przełamane przez województwo śląskie, w którym dotąd wybieranych było 13 senatorów, natomiast w świetle danych GUS maksymalna liczba mandatów może tu wynosić 12 . Kodeks nie precyzuje, któremu województwu miałby przypaść mandat, o który zmniejszyłaby się reprezentacja województwa śląskiego w przypadku zmiany. Wymaga zatem skorygowania liczby mandatów senatorskich przypadających na poszczególne województwa. To zaś oznacza konieczność ponownego wyznaczenia, w niektórych województwach, granic okręgów wyborczych. Omawiane tu rozwiązania opierają się na takiej właśnie korekcie. Modyfikacja ta została przygotowana w ten sposób, by umożliwić wytyczenie jak największej liczby okręgów sejmowych zgodnych z obowiązującym prawem, tak jak to uzasadniono w pierwszym z proponowanych rozwiązań. W przypadku tego rodzaju korekty granic okręgów senackich byłoby możliwe stworzenie dodatkowych 14 okręgów wyborczych, czyli zwiększenie ich liczby do 55. Takie rozwiązanie będzie w dalszym opracowaniu nazywane podziałem na 55 neutralnych okręgów.

Kolejny wariant również wytycza 55 okręgów wyborczych, jednak o bardzo wyraźnie zróżnicowanej wielkości. Taki podział - nazywany w dalszej części podziałem na 55 „skrzywionych” okręgów - przygotowany został według prostego algorytmu. Te okręgi senackie, w których poparcie dla Prawa i Sprawiedliwości było wyraźnie wyższe od średniej, pozostawiono jako okręgi sejmowe, liczące od trzech do siedmiu mandatów. Natomiast pozostałe okręgi senackie, w których wyniki PiS były słabsze, łączono w obrębie województw w duże okręgi. W największym z nich, obejmującym większość województwa śląskiego, rozdzielane byłyby 42 mandaty. Mapa pokazuje efekt takiego podziału z wyraźnie widocznym zjawiskiem - w Polsce południowo-wschodniej i centralnej okręgi wyborcze są małe, natomiast okręgi części zachodniej 
(z wyjątkiem Zagłębia Lubińskiego) są duże i obejmują całe województwa. Jednocześnie dużymi okręgami pozostają metropolie, przy czym do Warszawy dołącza się podmiejski okręg na zachód od stolicy, do Łodzi dołącza się okręg zgierski, a Kraków pozostaje oddzielnym okręgiem, powstałym z połączenia dwóch okręgów senackich.

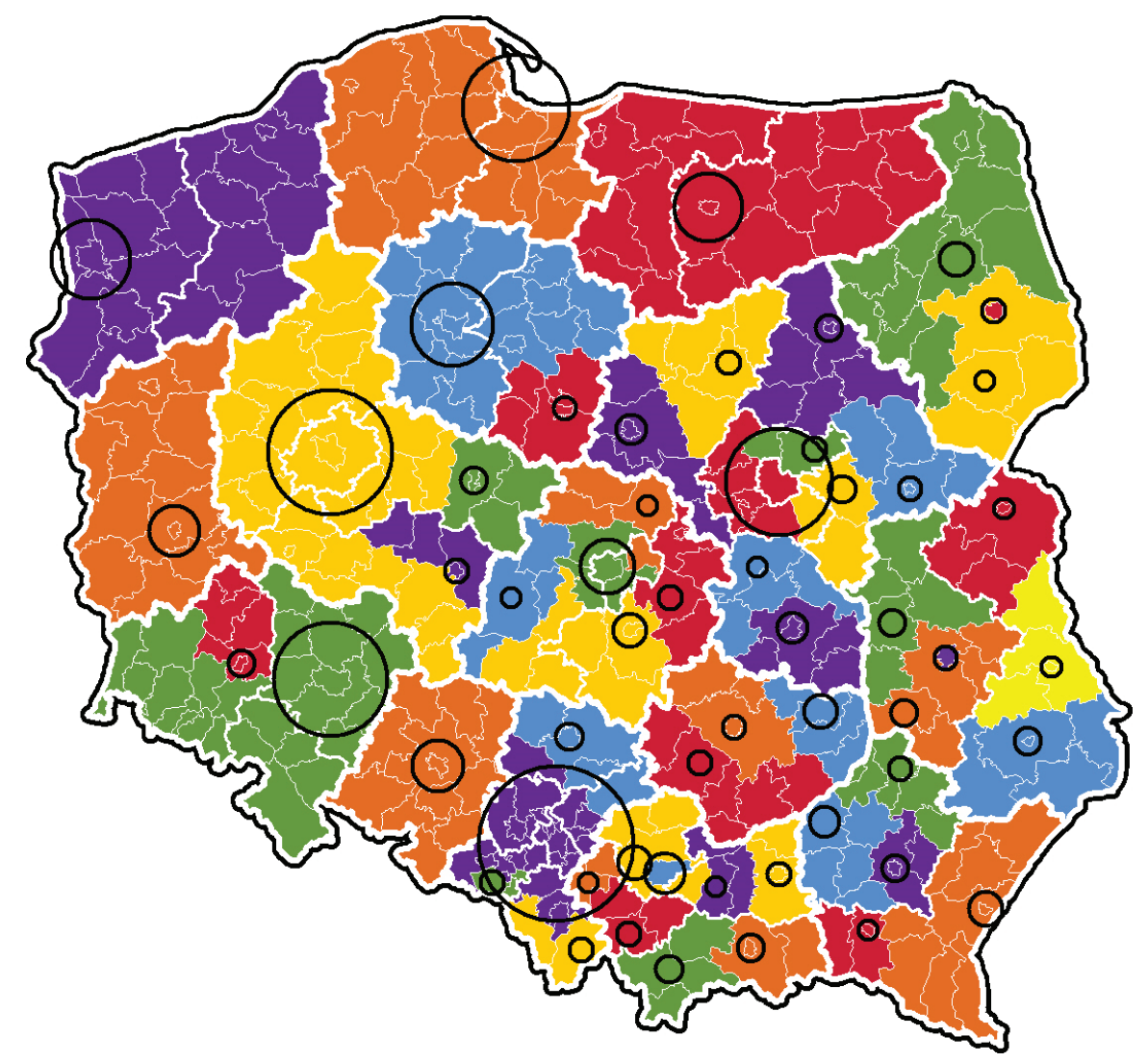

Mapa 1. Podział polski na 55 „skrzywionych” okręgów. Wielkość kręgu pokazuje liczbę mandatów przydzielonych każdemu z okręgów wyborczych

Źródło: opracowanie własne

Tak więc $w$ dalszych rozważaniach brane będą pod uwagę trzy scenariusze wszystkie oparte na zmodyfikowanym podziale na okręgi senackie. W pierwszym na podstawie okręgów senackich tworzy się 55 okręgów o zbliżonej wielkości, liczących co najmniej 7 mandatów, lecz nie większych niż 12 mandatów. W drugim tworzy się 55 okręgów o istotnie różnej wielkości (od 3 do 42 mandatów), w zależności od spodziewanego poparcia dla partii rządzącej. Zachowanie w obu wariantach tej sa- 
mej liczby okręgów umożliwia lepsze uchwycenie działania „skrzywionych” okręgów. W trzecim wariancie podział mandatów w wyborach sejmowych odbywa się w tych samych 100 okręgach, w których wybiera się senatorów. W okręgach takich rozdziela się od 3 do 7 mandatów.

Trzy rozważane rozwiązania zostały przetestowane na danych historycznych. Wszystkie wyznaczane na potrzeby tych rozwiązań okręgi zachowywały dotychczasowe granice powiatów (w przypadku Warszawy - granice gmin, natomiast w przypadku Wrocławia, Łodzi i Krakowa - podziały gmin zastosowane przy wyznaczaniu obecnych okręgów senackich). Na podstawie danych PKW zsumowano wyniki w powiatach tworzących poszczególne nowo wyznaczone okręgi. Tak uzyskane wyniki w każdym z okręgów przeliczono według standardowej procedury przewidzianej przez metodę d'Hondta. Wszystkie przedstawiane w dalszej części wyniki są efektem takiego właśnie przeliczenia.

Testowanie taką metodą pozwala porównać wyniki dla wszystkich rozwiązań. O ile w przypadku szacowania efektów obecnego podziału - na 55 neutralnych okręgów oraz wykorzystania 100 okręgów senackich - możliwe jest wykorzystanie wspomnianego modelu matematycznego systemu d'Hondta (Flis, Słomczyński i Stolicki, 2019), o tyle rozwiązanie z 55 skrzywionymi okręgami narusza jego fundamentalne założenia. Dlatego też w artykule ograniczono się do testów w oparciu o realne wyniki głosowania.

\section{TESTOWANIE MODELI Z WYKORZYSTANIEM DANYCH HISTORYCZNYCH}

\section{Z WYBORÓW Z LAT 2011 I 2015}

Rozpoczęcie testów poszczególnych rozwiązań od wyborów z 2011 roku nie wynika tylko z chronologii. Test taki pozwala sprawdzić, na ile realne są głosy, które widzą w zmianie struktury okręgów sposób na zabezpieczenie się przed utratą władzy na skutek porażki wyborczej. W wyborach tych PiS doznało jednoznacznej porażki. Dlatego warto się przyjrzeć temu, czy mogłaby być ona złagodzona zmianami ordynacji (wykres 1). Na wszystkich dalszych wykresach pokazujących podział mandatów partie uszeregowano ze względu na potencjalne koalicje - w taki sposób, aby pokazać, jakie większości są możliwe przy danym rezultacie wyborów.

Samo zwiększenie liczby okręgów do 55 neutralnych nie zmienia w zauważalny sposób wyników partii. PiS zyskuje 2 mandaty, natomiast zwycięzca wyborów - Platforma Obywatelska - dostaje dodatkowe 5 mandatów. Warto zwrócić uwagę, że takie rozwiązanie powoduje większe ubytki mandatów w przypadku Ruchu Palikota i SLD niż PSL. Jednak może to być efekt przypadkowy, zważywszy na niewielkie różnice. 


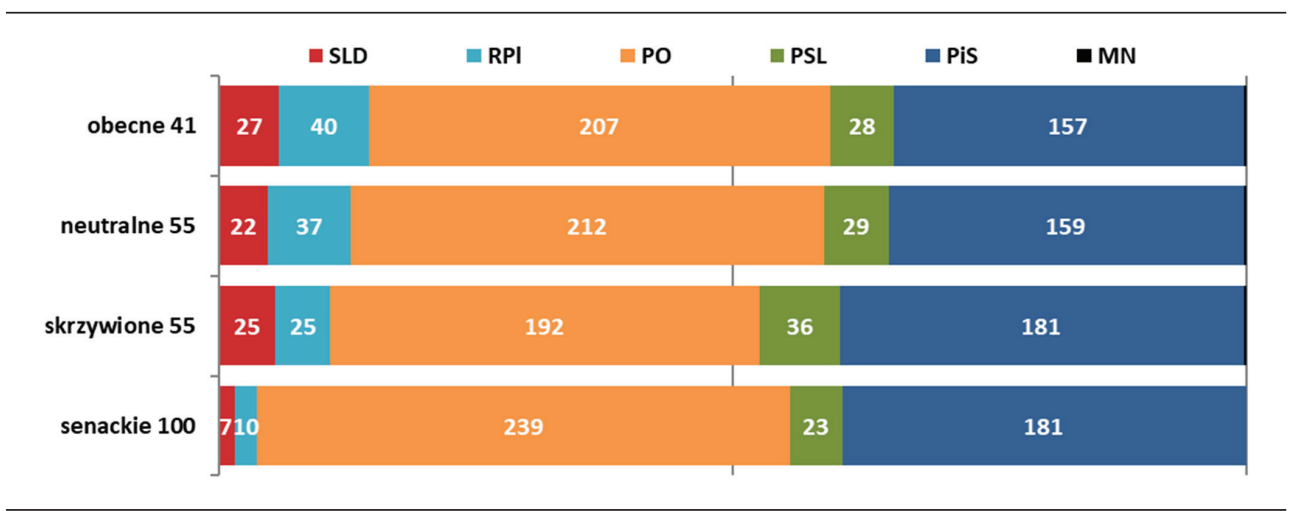

Wykres 1. Podziały mandatów na podstawie wyników głosowania z 2011 roku przy zmodyfikowanej liczbie okręgów

Źródło: opracowanie własne.

Bardzo wyraźne są natomiast efekty „skrzywienia” podziału na okręgi i zastosowania odmiennych standardów w zależności od tego, kto wygrywa w danej części kraju. PiS zyskuje na tym 24 mandaty. PO traci 15 mandatów i nie jest to rekompensowane przez dodatkowe 8 mandatów dla PSL. Tym samym koalicja PO-PSL traci większość. Niemniej zyski Prawa i Sprawiedliwości nie są na tyle duże, aby tworzyć koalicję, np. wspólnie z PSL. Koalicji PO-PSL brakuje do większości tylko 2 mandatów. Kluczowe pozostaje pytanie, które dwie spośród trzech mniejszych partii zwycięska Platforma Obywatelska dobierze jako koalicjantów do zbudowania większości. Nie jest to jednak radykalna zmiana sytuacji PiS.

W przypadku podziału kraju na 100 okręgów, Platforma Obywatelska zdobywa samodzielną większość, uzyskując 239 mandatów - przede wszystkim kosztem SLD i Ruchu Palikota. Straty PSL są w takim przypadku wyraźnie mniejsze. Prawo i Sprawiedliwość zyskuje zaś dokładnie tyle samo, co w przypadku 55 skrzywionych okręgów. Trudno jednak powiedzieć, by była to zmiana dla niego korzystna - główna konkurencyjna partia zyskuje dzięki niej pełną swobodę manewru. W każdym razie, również w tym wariancie nie kryje się żadna możliwość odwrócenia wyniku wyborów.

Analizując poziom dysproporcjonalności i koncentracji parlamentarnego systemu partyjnego przy wykorzystaniu powszechnie stosowanych w politologii mierników, można zauważyć, że tylko zastosowanie wariantu ze 100 okręgami senackimi powoduje zmianę formatu systemu partyjnego w kierunku dwupartyjności, co potwierdza również skok wskaźnika dysproporcjonalności systemu wyborczego. Pozostałe dwa warianty nie zmieniają praktycznie nic $\mathrm{w}$ zakresie formatu systemu partyjnego, zwiększają jednak znacząco stopień jego nieproporcjonalności. 
Tabela 1

Poziom dysproporcjonalności $i$ efektywna liczba partii parlamentarnych dla testowanych modeli na bazie wyników wyborów z 2011 roku

\begin{tabular}{ccc}
\hline Testowany wariant & Gh & ENP \\
\hline 55 neutralnych okręgów & 6,9 & 2,9 \\
\hline 55 „skrzywionych” okręgów & 8,1 & 2,9 \\
\hline 100 okręgów senackich & 13,7 & 2,3 \\
\hline obecny system & 5,9 & 3,0 \\
\hline
\end{tabular}

Gh - wskaźnik dysproporcjonalności (Gallagher, 1991); ENP - efektywna liczba partii parlamentarnych (Laakso

i Taagepera, 1979)

Źródło: opracowanie własne.

\begin{tabular}{|c|c|c|c|c|c|c|c|c|}
\hline & & $\square . \mathrm{N}$ & $\approx \mathrm{PO}$ & —PSL & Pis & $K^{\prime} 15$ & MN & \\
\hline obecne 41 & 28 & 138 & & 16 & & 235 & & 42 \\
\hline neutralne 55 & 22 & 140 & & 13 & & 239 & & 45 \\
\hline skrzywione 55 & 23 & 129 & & 19 & & 258 & & 30 \\
\hline senackie 100 & 14 & 159 & & 7 & & 269 & & \\
\hline
\end{tabular}

Wykres 2. Podziały mandatów na podstawie wyników głosowania z 2015 roku przy zmodyfikowanej liczbie okręgów

Źródło: opracowanie własne.

Samo zwiększenie liczby okręgów do 55 ma także w 2015 roku marginalny wpływ na wynik wyborów. Oznacza 4 dodatkowe mandaty dla Prawa i Sprawiedliwości, ale także 2 mandaty więcej dla Platformy Obywatelskiej. Zyskuje także Ruch Kukiz'15. Straty są udziałem najmniejszych partii, co jest zgodne z powszechną wiedzą na temat działania metody d'Hondta.

Natomiast skrzywienie okręgów i zróżnicowanie ich wielkości w poszczególnych częściach kraju rzeczywiście prowadzi do istotnych zysków dla zwycięskiego PiS. Stratne w takim systemie jest w pierwszej kolejności ugrupowanie Kukiz’15, które ma równomierne poparcie w całym kraju. Dlatego nie zdobywa o tyle więcej mandatów w większych okręgach, niż traci w tych mniejszych. Również Platforma Obywatelska i Nowoczesna składają się na zyski dla tych ugrupowań, które cieszą się wyższym poparciem w tej części kraju, gdzie wytyczone okręgi są mniejsze - a więc PiS i PSL. 
Przejście na 100 okręgów senackich daje jeszcze większą korzyść dla zwycięzcy. PO również zyskuje 20 mandatów. To wszystko odbywa się kosztem istotnego zmniejszenia liczby mandatów zdobywanych przez mniejsze partie - w szczególności przez Ruch Kukiz'15, który przy takim rozwiązaniu otrzymuje niewiele ponad 1/4 mandatów uzyskanych w obecnym systemie. Jego straty są zatem procentowo większe niż w przypadku pozostałych mniejszych ugrupowań. Dzieje się tak przede wszystkim dlatego, że zarówno Nowoczesna, jak i PSL są partiami o poparciu skupionym w części okręgów. Pozwala im to na zdobycie mandatu nawet wtedy, gdy okręgi te stają się mniejsze. Niemniej, w porównaniu do wyborów z 2011 roku, straty PSL są wyraźnie większe.

W przypadku wyborów 2015 roku dodatkowym testem jest sprawdzenie możliwych efektów integracji partii o zbliżonym profilu ideowym, czyli Platformy Obywatelskiej i Nowoczesnej, które w rzeczywistości stworzyły wspólną listę pod nazwą Koalicji Obywatelskiej w wyborach samorządowych 2018 roku. Przyjęto tu najprostsze - choć oczywiście dyskusyjne (Kamiński, 2001) - rozwiązanie, polegające na zsumowaniu wyników obu list i obliczeniu na tej podstawie nowego podziału mandatów (wykres 3).

\begin{tabular}{|c|c|c|c|c|c|c|}
\hline & $\approx$ KO & — PSL & Pis & —'15 & $\mathrm{MN}$ & \\
\hline obecne 41 & 177 & 15 & & 226 & & 41 \\
\hline neutralne 55 & 183 & 12 & & 228 & & 36 \\
\hline skrzywione 55 & 171 & 15 & & 244 & & 29 \\
\hline senackie 100 & 202 & & & 24 & & \\
\hline
\end{tabular}

Wykres 3. Podziały mandatów na podstawie wyników z 2015 roku po zsumowaniu głosów Platformy Obywatelskiej i Nowoczesnej, przy zmodyfikowanej liczbie okręgów Źródło: opracowanie własne.

Już w przypadku 55 neutralnych okręgów pojawia się wyraźnie większa nagroda integracyjna. $\mathrm{O}$ ile $\mathrm{w}$ obecnym systemie połączenie tych partii dawałoby 11 dodatkowych mandatów, o tyle w 55 okręgach nagroda za zjednoczenie wzrosłaby do 20 mandatów. Natomiast wynik Prawa i Sprawiedliwości byłby o 7-9 mandatów niższy niż w sytuacji braku takiego porozumienia. W obu przypadkach PiS traciłoby samodzielną większość w Sejmie. 
W wariancie podziału na 55 „skrzywionych” okręgów również widać straty zwycięzcy w przypadku porozumienia PO i Nowoczesnej. Są one nawet większe, jeśli wynik ten porównać z sytuacją osobnego startu PO i Nowoczesnej. Niemniej Prawo i Sprawiedliwość nadal zachowuje samodzielną większość pomimo zjednoczenia konkurentów, zatem korzyści z takiego systemu dla ugrupowania rządzącego są bardzo wyraźne.

Wreszcie bardzo podobny wynik, jeśli chodzi o zwycięską partię, ma miejsce przy przyjęciu podziału na 100 okręgów senackich w wyborach sejmowych. Znów bardzo wyraźnie widać tutaj zyski wynikające z połączenia Platformy Obywatelskiej i Nowoczesnej. Są one jeszcze większe niż w innych wariantach - wynoszą 35 mandatów. W takiej sytuacji dalszej redukcji ulega reprezentacja PSL i Ruchu Kukiz'15 - dochodzi do powstania duopolu w stopniu większym, niż w jakimkolwiek innym wariancie.

\section{Tabela 2}

Poziom dysproporcjonalności i efektywna liczba partii parlamentarnych dla testowanych modeli na bazie wyników wyborów z 2015 roku

\begin{tabular}{ccc}
\hline Testowany wariant & Gh & ENP \\
\hline 55 neutralnych okręgów & 13,3 & 2,7 \\
\hline 55 „skrzywionych” okręgów & 15,2 & 2,5 \\
\hline 100 okręgów senackich & 18,9 & 2,2 \\
\hline obecny system & 12,6 & 2,7 \\
\hline
\end{tabular}

Gh - wskaźnik dysproporcjonalności (Gallagher, 1991); ENP - efektywna liczba partii parlamentarnych (Laakso

i Taagepera, 1979)

Źródło: opracowanie własne.

Analiza wskaźników ponownie potwierdza, że model 100 okręgów senackich jest modelem najbardziej koncentrującym system partyjny i jednocześnie najbardziej dysproporcjonalnym. Poziom odchylenia od proporcjonalności sięgający prawie $20 \%$ jest już w tym przypadku bardzo wysoki i z całą pewnością nie może być uznany za proporcjonalny. Pozostałe rozwiązania nieznacznie tylko koncentrują system partyjny, zwiększając jednak wyraźnie, w porównaniu do obecnego systemu, nieproporcjonalność podziału.

\section{TESTOWANIE MODELI NA DANYCH Z WYBORÓW EUROPEJSKICH 2019 ROKU}

Ostatnim testem jest próba oszacowania wyników wyborów sejmowych w 2019 roku na podstawie wyników wyborów europejskich przeprowadzonych w tym samym roku. W wyborach europejskich próg wyborczy jest taki sam, jak w przypadku wyborów sejmowych. W poprzednich takich wyborach istotną różnicą była 
frekwencja znacząco niższa niż w przypadku wyborów sejmowych. Pod tym względem w 2019 roku zaszła zaskakująca zmiana. Ponad dwukrotny wzrost frekwencji (w porównaniu do wyborów z 2014 roku) przybliżył frekwencję do standardów wyborów sejmowych. Wyniki tych wyborów są niezmiernie ciekawe także z tego powodu, że zawiązana na ich potrzeby Koalicja Europejska doprowadziła do niespotykanej wcześniej polaryzacji sceny politycznej. Można dzięki temu sprawdzić, jakie skutki przynoszą w takiej sytuacji rozważane rozwiązania. Co prawda po wyborach pojawiły się deklaracje podważające sens takiej strategii koalicyjnych partii, niemniej same wyniki głosowania dostarczają tu bardzo ważnego testu możliwych efektów zmian w liczbie i kształcie okręgów wyborczych.

W wyborach europejskich 2019 roku bezprecedensowe co do skali zwycięstwo odniosło Prawo i Sprawiedliwość, zdobywając 45,4\% głosów. To nie tylko więcej niż zdobyła jedna partia w jakichkolwiek wyborach w ostatnich 30 latach, lecz także więcej niż wszystkie pozostałe partie przekraczające próg wyborczy razem wzięte. Równie ważne jest to, że także wynik drugiego ugrupowania był bezprecedensowy - w żadnych dotąd wyborach sejmowych żadna druga partia nie była tak silna (Koalicja Europejska zdobyła 38,5\% głosów). Natomiast trzecie ugrupowanie jeszcze nigdy nie było tak słabe - Wiosna Roberta Biedronia zdobyła 6,1\% głosów. Taki wynik potwierdza światowy trend, w którym poprawa wyniku zwycięzcy zmienia proporcje pomiędzy drugą a trzecią partią (Taagepera, 2007, s. 143-152).

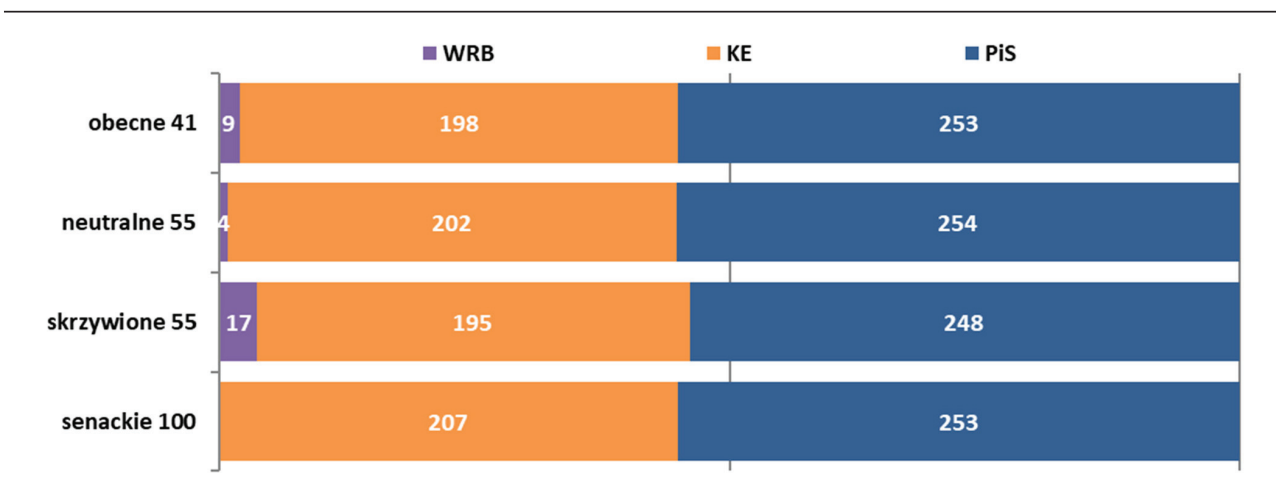

Wykres 4. Podziały mandatów na podstawie wyników głosowania w wyborach do Parlamentu Europejskiego w 2019 roku przy zmodyfikowanej liczbie okręgów

Źródło: opracowanie własne.

Uzyskane wyniki symulacji podziału mandatów są na pierwszy rzut oka zaskakujące. Przy takim poziomie polaryzacji, jaki przyniosły eurowybory 2019, dalsze po- 
większanie liczby okręgów wyborczych nie przynosi wartych odnotowania korzyści zwycięskiej partii. Modyfikacje okręgów - czy to dotyczące ich liczby, czy też kształtu - mają wpływ przede wszystkim na pozycję trzeciej partii: Wiosny Roberta Biedronia. W przypadku 100 okręgów jest ona całkowicie eliminowana przez naturalne progi wyborcze. W przypadku 55 neutralnych okręgów zdobywa tylko minimalną reprezentację. Natomiast skrzywione 55 okręgów znacząco polepsza jej wynik, także względem obecnego systemu. Najwyraźniej wydzielenie pewnej liczby bardzo dużych okręgów oznacza redukcję strat najmniejszej partii, co z nawiązką rekompensuje brak mandatów w części kraju podzielonej na mniejsze okręgi. Te zyski trzeciej partii odnoszone są przede wszystkim kosztem partii zwycięskiej.

\section{Tabela 3}

Poziom dysproporcjonalności i efektywna liczba partii parlamentarnych dla testowanych modeli na bazie wyników wyborów z 2019 roku

\begin{tabular}{ccc}
\hline Testowany wariant & Gh & ENP \\
\hline 55 neutralnych okręgów & 9,74 & 2,01 \\
\hline 55 „skrzywionych” okręgów & 8,06 & 2,12 \\
\hline 100 okręgów senackich & 10,20 & 1,98 \\
\hline obecny system & 9,12 & 2,05 \\
\hline
\end{tabular}

Gh - wskaźnik dysproporcjonalności (Gallagher, 1991); ENP - efektywna liczba partii parlamentarnych (Laakso i Taagepera, 1979)

Źródło: opracowanie własne.

Przy takich wynikach znaczenie liczby okręgów dla dysproporcjonalności i efektywnej liczby partii jest marginalne. Wszystkie analizowane modele są zarówno dysproporcjonalne, jak i koncentrujące, choć tradycyjnie wariant „senacki” jest systemem najmocniejszym. Dane te potwierdzają wnioski wyprowadzane z modelu matematycznego - zmniejszenie liczby partii ma zasadnicze znaczenie dla zmniejszenia nagrody dla zwycięzcy wyborów. System d'Hondta raz jeszcze potwierdza swoje właściwości samoregulującego się mechanizmu - jeśli dochodzi do dwustronnej integracji systemu partyjnego, nagroda integracyjna ma coraz mniejsze znaczenie.

\section{WNIOSKI}

Przeprowadzone symulacje pozwoliły prześledzić wpływ modyfikacji systemu wyborczego przy zmianie struktury okręgów wyborczych (zwiększenie lub zmiana kształtu okręgów) bez modyfikacji pozostałych jego parametrów. Po pierwsze, w każdym z tych rozwiązań kryje się potencjał zwiększenia zysków partii zwycię- 
skiej. Nie jest on jednak wcale oczywisty. Ponadto, nawet w przypadku istotnego zwiększenia liczby okręgów o $1 / 3$, zmiany mogą być trudne do uchwycenia i zupełnie marginalne. Efekty są wtedy zbliżone do standardowego, przypadkowego rozchwiania wyników, związanego z różnicami we frekwencji i nieuchronnymi zaokrągleniami w rozdziale mandatów w systemie d'Hondta w poszczególnych okręgach. Te systemy, które zmieniają wyniki radykalnie, podlegają z kolei mechanizmowi samoregulacji. Im większa jest nagroda dla zwycięzcy, tym większa jest też zachęta dla jego oponentów do jednoczenia się. Taka integracja konkurentów w większości przypadków odbiera lwią część zysków z manipulacji, a nawet może prowadzić do straty względem punktu wyjścia.

Na polu strategicznych przegrupowań już obecny system pokazał swoją siłę. Cała debata dotycząca jednoczenia się opozycji, którą toczono pomiędzy wyborami samorządowymi a europejskimi, była prowadzona pod wpływem spodziewanych efektów systemu wyborczego w wyborach sejmowych 2019 roku. Doświadczenie wyborów europejskich uświadomiło wielu uczestnikom polskiego życia politycznego wspomniane wyżej ograniczenia w addytywności elektoratów. Sam fakt matematycznych korzyści z jednoczenia jest jednak stale podkreślany także w komentarzach do sytuacji po tych wyborach.

Wracając jednak do propozycji zmiany liczby i kształtu okręgów, bardzo trudne do oszacowania są takie czynniki, których pominięcie w kalkulacjach byłoby na pewno nieracjonalne, czyli: zmiana zachowania wyborców w warunkach nowego systemu; negatywne reakcje opinii publicznej w przypadku braku racjonalnych, wiarygodnych argumentów na rzecz danej zmiany, odwołujących się do dobra wspólnego, nie zaś wyłącznie do chęci zdobycia dodatkowych mandatów przy takiej samej liczbie zdobytych głosów; zwiększenie napięć terytorialnych w obrębie okręgów i pomiędzy różnymi częściami kraju; zmiana motywacji poszczególnych kandydatów i struktur partii wobec nowych warunków obsadzania miejsc na listach oraz prowadzenia kampanii wyborczej. Niepewność na tym polu powinna być argumentem przeciw ewentualnym zmianom.

Wbrew głosom podnoszonym w przywołanej we wstępie do tego tekstu publicystyce, nie ma na tym obszarze rozwiązań prostych, oczywistych i przynoszących pewne zyski. Obecna liczba okręgów i sposób przeliczania głosów na mandaty zapewnia całkiem racjonalny poziom nagrody dla zwycięzcy. Poziom, który jest już znany uczestnikom życia politycznego i może być brany pod uwagę przy wszystkich kalkulacjach strategii i planów. Pojawiające się w debacie inne rozwiązania nie zmieniają aż tak wiele, by stanowiły pokusę dla racjonalnych aktorów politycznych. 


\section{BibLIOGRAFIA}

Colomer, J.M. (2004). The Handbook of electoral system choice. London: Palgrave Macmillan.

Drinóczi, T. (2014). Nowe prawo wyborcze na Węgrzech i jego implikacje. Studia Wyborcze, 18, $85-100$.

Flis, J. (2014). Złudzenia wyboru. Kraków: Wydawnictwo Uniwersytetu Jagiellońskiego.

Flis, J., Michalak, B. (2017). Mieszany system wyborczy - cztery warianty dla Polski. Athenaeum. Polskie Studia Politologiczne, 55, 65-88. doi: 10.15804/athena.2017.55.04

Flis, J., Stolicki, D. (2015). Skrzywione podziały: na tropie gerrymanderingu w polskich gminach. Zarzadzanie Publiczne, 4(34), 23-35.

Flis, J., Słomczyński, W., \& Stolicki, D. (2019). Pot and ladle: a formula for estimating the distribution of seats under the Jefferson-D'Hondt method. Public Choice, 1-27.

Gallagher, M. (1991). Proportionality Disproportionality and Electoral Systems. Electoral Studies, 10(1), 33-51.

Gallagher, M. (2005). Conclusion. W: Gallagher, M., Mitchell, P. (red.), The Politics of Electoral Systems. Oxford-New York: Oxford University Press.

Grochal, R. (6 czerwca 2016). Czy PiS zmieni zasady wyborów? Eksperci szukaja sposobu na drugq kadencje. http://wyborcza.pl/1,75398,20191719,czy-pis-zmieni-zasady-wyborow-eksperci-szukaja-sposobu-na-druga.html

Grofman, B., Koetzle, W., Brunell, T. (1997). An integrated perspective on the three potential sources of partisan bias: Malapportionment, turnout differences, and the geographic distribution of party vote shares. Electoral Studies, 16(4), 457-470. doi: 10.1016/S0261-3794(97)00037-1

Haman, J. (2003). Demokracja, decyzje, wybory. Warszawa: Wydawnictwo Naukowe Scholar.

Haman, J. (2017). Progresywna proporcjonalność jako cecha systemu wyborczego. Decyzje, 27, 69-88. doi: 10.7206/DEC.1733-0092.86

Kaminski, M.M. (2001). Coalitional Stability of Multi-Party Systems: Evidence from Poland. American Journal of Political Science, 45(2), 294-312.

Kedar, O., Harsgor, L., Sheinerman, R.A. (2015). Are Voters Equal under Proportional Representation? American Journal of Political Science, 60(3), 376-691.

Koellner, P. (2005). The LDP at 50: The Rise, Power Resources, and Perspectives of Japan's Dominant Party. Working Papers Global and Area Studies, 8, 10-11.

Kublik, A., Markowski, R. (16 kwietnia 2016). Kaczyński po wsze czasy. Wystarczy manipulować 5 czy 6 mln Polaków. http://wyborcza.pl/1,75398,19927339,kaczynski-po-wsze-czasy-wystarczy-manipulowac-5-czy-6-mln-polakow.html

Laakso, M., Taagepera, R. (1979). Effective Number of Parties: A Measure with Application to West Europe. Comparative Political Studies, 12(1), 3-27.

Lachat, R., Blais, A., Lago, I. (2015). Assessing the Mechanical and Psychological Effects of District Magnitude. Journal of Elections, Public Opinion and Parties, 25(3), 284-299. doi: $10.1080 / 17457289.2014 .1002791$ 
Markowski, R. (2010). System wyborczy - system partyjny - jakość demokracji. O jednomandatowych okregach wyborczych. Warszawa: Instytut Spraw Publicznych.

Noch, J. (16 stycznia 2016). „Wtadzy raz zdobytej nie oddamy nigdy...”. 230 JOW-ów i 16 list wojewódzkich to sposób PiS na nietykalność w wyborach. https://natemat.pl/168079,230-jow-ow-i-16list-wojewodzkich-oto-sposob-pis-by-nigdy-nie-stracic-zdobytej-wreszcie-wladzy

Nohlen, D. (2004). Prawo wyborcze i system partyjny. O teorii systemów wyborczych. Warszawa: Wydawnictwo Naukowe Scholar.

PAP (17 października 2017). 100 okręgów wyborczych zamiast 41? Karczewski: to ciekawa propozycja. https://www.tvp.info/34427217/

Raciborski, J. (2006). Teoria demokracji a reguły wyborów. Nauka, 3, 27-44.

Rae, D. (1967). The Political Consequences of Electoral Laws. New Hale: Yale University Press.

Reynolds, A., Reilly, B., Ellis, A. (2008). Electoral system design: The new international IDEA handbook. Stockholm: International Institute for Democracy and Electoral Assistance.

Schuster, K., Pukelsheim, F., Drton, M., Draper, N.R. (2003). Seat biases of apportionment methods for proportional representation. Electoral Studies, 22(4), 651-676.

Taagepera, R. (1986). Reformulating the cube law for proportional representation elections. American Political Science Review, 80(2), 489-504.

Taagepera, R. (2007). Predicting Party Sizes. The Logic of Simple Electoral Systems. Oxford: Oxford University Press.

Taagepera, R., Laakso, M. (1980). Proportionality profiles of west European electoral systems. European Journal of Political Research, 8(4), 423-446.

Taagepera, R., Sikk, A. (2010). Parsimonious Model for Predicting Mean Cabinet Duration On the Basis of Electoral System. Party Politics, 16(2).

Taagepera, R., Shugart, M.S. (1989). Seats and Votes. The Effects and Determinants of Electoral Systems. New Haven \& London: Yale University Press.

Tóka, G. (2014). Constitutional Principles and Electoral Democracy in Hungary. W: Bos, E., Pócza, K. (red.), Verfassunggebung in konsolidierten Demokratien (s. 309-329). Baden-Baden: Nomos Verlagsgesellschaft mbH \& Co. KG. 